\title{
Bilgisayar, Telefon ve Kulaklık Üçgeninde Çağrı Merkezinde Duygusal Emek Süreçleri: Bir Saha Çalışmasının Sonuçlarıyla Yüzleşmek ${ }^{*}$
}

\author{
Hande KÖSE ${ }^{1}$ \\ ORCID: 0000-0002-3784-5731
}

Fuat GÜLLÜPINAR ${ }^{2}$

ORCID: 0000000336617232

DOI: $10.54752 /$ ct.1060786

\begin{abstract}
Öz: Bu çalışma, sınıfsal bir bakış açısıyla, denetimin ve gözetimin bilgisayarlar aracılı̆̆ıyla yoğunlaştırıldı̆̆ı çağrı merkezi çalışanlarının neoliberal çalışma koşullarında deneyimledikleri duygusal emek süreçlerine ve bu süreçlerin çalışma koşullarıyla olan ilişkisine odaklanmaktadır. Çağrı merkezlerinde, çalışmanın bilgisayar - telefon - kulaklık üçgeninde gerçekleştirilmesi, çağrı merkezi çalışanları üzerindeki denetim mekanizmalarını da bu araçların özgül yapılarından dolayı diğer sektörlere göre farklılaştırmaktadır. Buradan hareketle çalışmada çağrı merkezi çalışanlarının çalışma koşulları bağlamında sıkı denetim mekanizmalarının, çağrı merkezlerindeki çalışma koşullarını ve duygusal emek sürecini nasıl şekillendirdiğinin açıklanması amaçlanmaktadır. Duygusal emek perspektifi temel alınarak bu araştırmanın kapsamında çağrı merkezi çalışanlarının meslek algıları, çalışma koşulları, sarf ettikleri duygusal emek sürecinin psikolojik ve sosyal ilişkilere etkileri ve sonuçları ele alınmaktadır. Ayrıca, çalışmada Covid-19 pandemisiyle yaygınlaşan evden çalışma pratiklerinin çağnı merkezi çalışanlarına ne ölçüde ve nasıl yansıdığı da ele alınmıştır. Nitel araştırma modelinin kullanıldığ1 çalışmada çağnı merkezi çalışanlarıyla ve bu sektörde faaliyet gösteren sendika çalışanlarıyla yarı-yapılandırılmış derinlemesine görüşmeler ve odak grup görüşmeleri gerçekleştirilmiştir. Araştırma kapsamında 24 çağrı merkezi çalışanıyla ve 2 sendika yetkilisiyle görüşme gerçekleştirilmiştir. Görüşülen çağr1 merkezi çalışanları telekomünikasyon, e-ticaret ve bankacılık sektörlerinde çalışmaktadır. Araştırma sonucunda çağrı merkezi çalışanlarının çalışma koşulları göz önünde bulundurulduğunda oldukça yoğun biçimde duygusal ve duygulanımsal emek sarf ettikleri görülmüştür. Çalışanların uzun çalışma ve mesai saatlerinin, yoğun ve standardize edilmiş iletişim biçimleriyle
\end{abstract}

Bu makale, "Çağrı Merkezi Operatörlerinin Çalışma Koşulları Üzerine Sosyolojik Bir Analiz: Hizmet Sektöründe Duygusal Emek ve Sonuçları” başlıklı yüksek lisans tezinden derlenerek üretilmiștir.

${ }^{1}$ Anadolu Üniversitesi Sosyal Bilimler Enstitüsü Sosyoloji Anabilim Dalı Doktora Öğrencisi,

2 Prof. Dr., , Anadolu Üniversitesi Edebiyat Fakültesi Sosyoloji Bölümü,

Makale Gelis Tarihi: 02.09.202.1 Makale Kahul Tarihi: 27.12.2.02.1

Çalışma ve Toplum, 2022/1 
görüşmeler yapmalarının ve sürekli olarak mekanikleştirilmiş bir eğitimden geçerek 'müşterilerin her zaman haklı olduğu' anlayışının dayatılmasının, onların psikolojik ve sosyal ilişkilerini ağır biçimde etkilediği tespit edilmiştir. Çalışanlar gün içinde sürekli müşterilerle konuştukları için aileleriyle ve sosyal çevresiyle iletişim kurmak istememekte, günlük hayatlarındaki olumsuz meselelere tahammül edememekte, sosyal ilişkilerinde tolerans göstermekte zorlanabilmektedir.

Anahtar Kelimeler: Neoliberalizm, duygusal emek, esnek çalışma, kuralsız çalışma, çağnı merkezi, hizmet sektörü.

Emotional Labor Processes in the Call Center in the Triangle of Computer, Telephone and Headset: Confronting the Consequences of A Fieldwork

Abstract: From a class point of view, this study focuses on the emotional labor experienced by call center employees, where control and surveillance are intensified through computers, and the relationship of these experiences with working conditions. In call centers, the fact that the work is carried out in the triangle of computer - phone - headset differentiates the control mechanisms on call center employees from other sectors due to the specific structures of these tools. From this point of view, it is aimed to explain how strict control mechanisms shape the working conditions and emotional labor processes in call centers, in the context of working conditions of call center employees. Based on the emotional labor perspective, within the scope of this research, their perceptions of their profession, working conditions, the effects and results of the emotional labor process they expend on psychological and social relations are discussed. In addition, the extent and how the work from home practices, which have become widespread with the Covid-19 pandemic, are reflected on the call center employees are also discussed in the study. In the article, in which the qualitative research model was used, semi-structured in-depth interviews and focus group interviews were conducted with call center workers and union workers operating in this sector. Within the scope of the research, 24 call center employees and 2 union officials were interviewed. The interviewed call center employees work in the telecommunications, e-commerce and banking sectors. As a result of the research, considering the working conditions of the call center employees, it was seen that they made a very intense emotional and affective labor. It has been determined that the long working and working hours of the employees, the intense and standardized forms of communication, and the imposition of the understanding that "customers are always right" through a constantly mechanized training affects their psychological and social relationships heavily. Employees do not want to communicate with their families and social environment because they constantly talk to customers during the day, cannot tolerate negative issues in their daily lives, and may have difficulty in tolerating their social relations.

Keywords: Emotional labor, flexible working, irregular employment, call center, service sector 


\section{Giriş}

Emek, tarihsel olarak bakıldığında her türlü insan üretiminin var olduğu her toplumda farklı biçimleriyle ele alınmaktadır. Genel anlamda sermayenin birikimi ve bu birikim süreçlerinin geçirdiği dönüşümler emek olgusunu da değişime uğratmaktadır. Günümüzün kapitalist üretim sisteminde de bu dönüşüm kendisini giderek esnekleşme, uzmanlaşma ve güvencesizleşme şeklinde göstermektedir. Üretim alanında esnek üretim biçimlerinin ivme kazanması ve çalışanların giderek daha esnek, güvencesiz bir çalışma ortamında çalışmak zorunda kalmaları günümüz kapitalizminin karakterini oluşturmaktadır. Bu esnekleşme ve güvencesizleşme pratikleri çağnı merkezlerinde de mevcudiyetini giderek arttırmaktadır. Çağn1 merkezleri, özellikle 21. yüzyılın başlarından itibaren gerek nicel anlamda çalışan istihdamının artması gerekse nitel anlamda çalışma politikalarının değişen teknolojik gelişmelerle birlikte ilerletilmesiyle son yılların en hızlı ivme kazanan sektörlerinden biri haline gelmektedir. Bu bağlamda çağrı merkezleri son otuz yılın giderek bağımsızlaşan, hiyerarşik yapıları kıran ve zaman - mekan bağımlılı̆̆ından azade olan mekanlar olarak ele alınmaktadır (Yücesan - Özdemir, 2014, s. 17). Ayrıca çağrı merkezlerinin günümüz üretim biçimleri arasındaki bir diğer önemli niteliği ise çağrı merkezlerinde gerçekleştirilen üretimin doğrudan insan iletişimine dayanmasında yatmaktadır. Bu durum da çağrı merkezi çalışanlarının fiziksel ve zihinsel emek sarf etmelerinin yanı sıra yoğun biçimde duygusal emek sarf etmelerini de gerekli kilmaktadir.

Duygusal emek ilk defa Arlie Hochschild tarafindan 1983 y1linda sosyal aktörlerin günlük yaşamlarında sergiledikleri eylemliliklere atıfla kullanılmıştır. $\mathrm{Bu}$ noktada Hochschild'e göre iletişim kurulan kişide belli duyguları uyandırabilmek amacıyla duyguların yönetilmesi ve bu yönetim sürecinin bir ücret karşılığ yapılması duygusal emek olarak tanımlanmaktadır. Duygusal emek sürecinin çıktısı da telefonun ucundaki müşteride belirli bir duygunun meydana getirilmesidir (Hochschild, 1983, s. 7). Duygulanmsal emek ise duygusal emeğin aksine yalnızca çalışma zamanı ve mekanıyla sınırlı kalmayan ve tüm yaşamı etkisi altına alan bir süreç olarak tarif edilmektedir. Sonuç olarak duygusal emek ve duygulanımsal emek kavramları, emeğin ilişkiselliği ve bedensel denetime vurgu noktasında benzeşmekle birlikte belirli bir çalışma mekânı ve çalışma süresi gerektirme noktasında ayrilmaktadır (Karaman, 2017, s. 50-51).

Duygusal emek kavramını tüm yaşama sirayet etmesi bakımından duygulanımsal emek biçiminde genişleten Antonio Negri'ye göre duygulanımsal emek, kapitalizmin her aşamasında öyle ya da böyle bir şekliyle var olmuştur. İş ilişkileri doğal olarak insanın bedeniyle de ilişki kurmasına dayandığı için duygulanımsal emeği bir şekliyle içermektedir. Ancak bugün özellikle hizmet sektöründe duygulanımsal emeğin öne çıkması ve önem kazanmasının sebebi, kapitalizmin artık insanların bedenlerini ve duygularını da metalaştırarak her türlü insani ilişkiyi ve duygusal durumu sermaye birikim aracı olarak kullanmasında yatmaktadır (Koşar, 2017, s. 93). Üretim süreçlerinin doğrudan bedene vurgu yapar hale gelmesi, duygulanımsal emek teorilerinin altını çizmeye çalıştığı nokta olarak da belirtilmektedir (Akalın, 2007, s. 121). Buradan hareketle maddi olmayan emek ve duygusal emek tartışmalarının odak noktasının üretim ilişkilerinin dönüşüme uğradığ1, üretimde makineleşme ve teknolojik gelişmelerle birlikte işçi sınıfının niteliğinin de değiştiği, böylece günümüz toplumunu açıklamakta sınıfsal analizlerin yetersiz kaldığ1 gibi tezler ortaya çıkmıştır. Bu nedenle 1960 - 1970’li yıllarla birlikte gelişen ve günümüz kapitalist toplumunu postkapitalist toplum, enformasyon toplumu, bilgi toplumu gibi çeşitli 
biçimlerde tanımlayan görüşler ivme kazanmıştır. Bu tezlerin ortaya çıkmasının toplumsal ve tarihsel açıdan birçok sebebi bulunmaktadır. Öncelikle 1970'li yıllar tüm dünyada küreselleşme sürecinin hızlandığ1 bir döneme tekabül etmektedir ve küreselleşme süreçleri kültürel etkileşimi arttırmanın yanı sıra ekonomi politikalarında da köklü değişiklikler meydana getirmiştir. Ayrıca sonraki yıllarda Sovyet Sosyalist Cumhuriyetler Birliği'nin yıkılmasıyla birlikte Amerika Birleşik Devletleri'nin "tek süper güç" olarak dünya sahnesinde yerini alması; işçi sınıfının devrimci gücünü yitirdiği, sosyalizmin başarısızlığa uğradığ1 ve kapitalizmin nihai zaferini ilan ettiği görüşünü sağlamlaştırmıştır. Ancak dünyada meydana gelen bu değişimler, üretimde meydana gelen değişimlerden bağımsız ele alınamamaktadır. Üretimdeki değişimler devletlerin ekonomi politikalarına doğrudan etki etmekte ve devletler çalışma hayatıyla ilgili programlarını üretici güçlerin sınıfsal eylemliliklerine ve üretim ilişkilerine paralel olarak hazırlamak durumunda kalmaktadır. $\mathrm{Bu}$ nedenle politik açıdan dünyanın izlediği bu seyrin, üretim ilişkileri açısından da açıklanması gerekmektedir.

\section{Üretim İlişkilerinin Dönüşümü, Esnek Üretim Süreçleri ve Duygusal Emek}

Tarihsel açıdan kapitalizmin izlediği seyre bakıldığında 1960’lı yıllara kadar üretimin sanayi iş kolunda ve genellikle kol emeğine dayalı olduğu görülmektedir. Sanayi iş kolunun ekonomideki bu geniş yeri, 19. yüzyılın sonlarında fabrikalarda Taylorist üretim biçiminin de yaygınlaşmasıyla hem üretimi rasyonelleştirmiş hem de yönetim ve denetim mekanizmalarını katılaştırmıştır. En az maliyetle en yüksek verimin alınmasının hedeflendiği bu üretim biçimi, kapitalizme ilk kez bedensel ve zihinsel emeği birbirinden ayırma firsatı vermiştir. Böylece seri üretimin arttırılması amaçlanmıştır. Taylorizmin bu verimlilik mantığı, 20. yüzyılın başlarına gelindiğinde Henry Ford ve Ford fabrikalarının öncülüğünde Fordizm adı verilen bir üretim biçiminin gelişmesine olanak tanımıştır. Fordizm, Taylorist üretim biçiminin akılcılığını temele alarak bu akılcılık stratejilerini teknolojik gelişmelerle birleştirmiş ve kitlesel üretimin gerçekleştirilmesinin önündeki büyük adımların atılmasını sağlamıştır. Fordizmde genel olarak vasıflı olmayan işçilerin bir bant veya montaj hattı üzerinde devamlı aynı işi yapmalarını merkeze alan bir üretim anlayışı hakimdir. İşçilerin her biri tek bir montaj hattında çalışmakta ve üretilen ürünün yalnızca bir parçasından haberdar olmakta, muhtemelen ürünün tamamını bile görmemektedir. $\mathrm{Bu}$ sistemde üretim standardize edilmiş, tek bir işyerinde ya da fabrikada merkezileştirilmiştir (Başçı, 2018, s. 1415). 1970 'ler öncesinin hakim üretim biçimi olan fordizm, bu yönüyle tek tip ve seri üretime dayalı olan bant üretimini esas almıştır. Fakat fordizmin bu teknik özelliklerinin yanında David Harvey'e göre fordizm yalnızca kitle üretimi olarak değil, bütünsel bir yaşam tarzı olarak ele alınmalıdır (Harvey, 2014, s. 158). Çünkü fordist üretim tarzı fabrikalarda çalışan işçiler, tek tip üretim yaparken aynı zamanda ortak bir kültürü de paylaşmaktadır.

1960'lara gelindiğindeyse üretimin karakteri, doğrudan fabrikada kol emeğini satan işçi sınıfıyla açıklanamamaktadır. Bu açıdan bedensel üretim, işçi sınıfını ve kapitalist üretimi analiz ederken tek başına bir anlam ifade etmemeye başlamaktadır. Fordist üretim tarzının katıllğı̆ın ve otoriterliğinin kademeli olarak terk edilerek Toyotist üretim tarzının yaygınlık kazanmaya başlaması, bu tezlerin pratik temeller kazanmasının önünü açmışır. 1940’ların başlarında Toyotist üretim tarzı yine bir otomobil firması olan Toyota'nın fabrikalarında uygulanmaya başlanmış ve sonraları günümüze uzanarak yaygınlık kazanmıştır. Bu üretim 
tarzının Taylorist/Fordist üretim tarzına nazaran daha katılımcı, daha demokratik, daha esnek ve daha insancıl olduğu savunulmaktadır (Akpınar, 2016, s. 55). Çünkü bant üretimi ve tek tip üretimin yerini daha çeşitli tarzda ve daha kompleks makinelerle gerçekleştirilen üretim almıştır. Bu üretim tarzı, maddi olmayan emek tartışmalarının yönünü de etkilemiştir. Hardt ve Negri, Toyotist üretim tarzından aldıkları referansla üretim biçiminin emeğin biçimini nasıl değiştirdiğini açıklamaktadır. Hardt ve Negri'ye göre Toyotist üretim tarzıyla ve hizmet sektöründe teknolojik araçların kullanımının artmasıyla bilgisayarlar, kendilerini tüm işleri gerçekleştirebilecek olan ana üretim aracı olarak sunmaktadır. Buradan hareketle üretimin bilgisayarlaşması, emeği soyutlaştırmaktadır. Ancak bu vurgu, yalnızca maddi olmayan emeğin bir yönüne aittir (Hardt ve Negri, 2003, s. 305). Maddi olmayan emeğin diğer bir yönü olarak duygulanımsal emek, bu emek biçimini de aşmakta ve kendisini toplumsal pratiklerin her alanında göstermektedir.

Günümüzde postfordist üretim olarak da adlandırılan bu üretim biçimi, makineleşmeyle birlikte daha az işçiye ihtiyaç duyulmasını beraberinde getirmiştir. Üretim biçiminin bu şekilde değişmesi işçi sınıfına ihtiyaç duyulmayacağı, böylece işçi sınıfinda mevcut olan ekonomik ve toplumsal gücün herhangi bir toplumsal dönüşüme yol açamayacağı görüşlerinin daha geniş kitleler tarafindan tartışılmasına sebep olmuştur. $\mathrm{Bu}$ açıdan postkapitalist toplum tezlerine göre üretimde makineleşme vasıflı ve teknik iş gücüne ihtiyacı da arttırdığından kütlesel nitelikteki vasıfsız emek gücüne bağımlılık dönemi sona ermektedir. Tüm bu gelişmelerin işı̆̆ında postkapitalist toplum tezlerinin önermeleri şu şekilde özetlenmektedir: İşçi sınıfının nicel ve nitel bakımdan kuvvetli olduğu ileri kapitalist ülkelerde özellikle İkinci Dünya Savaşı sonrasında yaşanan teknolojik gelişmeler, başta bu ülkeler olmak üzere tüm dünya ekonomisinde köklü değişikliklere yol açmıştır. Bu teknolojik gelişmeler sayesinde uzmanlaşmanın da artmasıyla birlikte yeni işkolları ve yeni meslekler ortaya çıkmıştır. Mülkiyet ile yönetim ilişkilerinin ayrılması sonucunda ise sermayenin yöneticilik ve denetleme işlevini üstlenebilen yeni orta sınıf gelişmiştir ve giderek küreselleşen dünyada üretim artık doğrudan dünya pazarına yönelik ve dünya ölçeğinde gerçekleştiğinden, ulusal ekonomiler ve ulus-devletler önemini kaybetmiştir. Küreselleşme sürecinin bir sonucu olarak da çokuluslu şirketler ortaya çıkmış ve özellikle ileri kapitalist ülkelerde sanayinin yerini giderek hizmet sektörü almaya başlamıştır (Cengiz, 1998). ${ }^{3}$ Ayrıca bu dönemde geliştirilmeye başlanan refah devleti ve sosyal güvenlik politikaları sonucunda işçi sınıfının yaşam koşulları iyileştirilmeye başlanmış, işçi sınıfına çeşitli haklar tanınmış ve "vahşi kapitalizm”in sonunun geldiğine kanaat getirilmiştir.

Postkapitalist toplum tezlerini ortaya çıkaran ekonomik, toplumsal ve siyasal etmenler düşünüldüğünde özellikle üretimin esnekleşmesi, hizmete ve teknik bilgi-beceriye dayalı işkollarının ortaya çıkmasıyla kapitalist toplumlardaki sınıf yapısının değişime uğradığını söylemek mümkündür. Fakat fordist üretim biçiminden postfordizme geçiş nasıl ki keskin biçimde ayrıştırılamazsa -ki günümüzde fordizm halen yaygın bir üretim biçimi olmaya devam etmektedir- ortaya çıkan yeni orta sınıfla birlikte işçi sınıfının yok olduğunu da iddia etmek mümkün değildir. Beyaz yakalı olarak sınıflandırabileceğimiz öğretmenlik, avukatlık, bankacılık ve hatta doktorluk gibi meslekler düşünüldüğünde bu mesleklerin de

3 Türkiye'de sektörel istihdam açısından 2020 yılı istatistiklerine bakıldığında bir önceki yıla göre sanayi sektöründe 50 bin, hizmet sektöründe ise 399 bin artış gözlenmiştir: https://ozgurlukdunyasi.org/arsiv/342-sayi-091/1285-qkapitalizm-otesiq-tezler-ve-isci$\underline{\text { sinifi/ }}$ 
çalışma koşulları bakımından giderek "işçileştĭgii” dahi söylenebilmektedir (bknz.: 2009, Man ve Selek Öz; 2013, Kaya ve Serçeoğlu; 2015, Savul; 2015, Uca). Çünkü güvencesiz çalışma, esnek çalışma, taşeronlaşma gibi problemler günümüz toplumunun problemleri olarak var olmaya devam etmektedir ve yalnızca sanayi kolunda çalışan işçileri değil tüm sınıfsal konumlar1 etkilemektedir.

Neoliberal ekonomi politikalarıyla hız kazanan esnek üretim süreçlerini mesai kavramının silikleşmesi, evden çalışma, esnek çalışma, kuralsız istihdam, sözleşmeli çalışma, proje tabanlı çalışma, yarı-zamanlı çalışma vb. gibi birçok örnekle somutlamak mümkündür. Bu tür esnek istihdam biçimleri işçilerde güçlü bir hoşnutsuzluk yaratmamaktadır çünkü bu biçimler her iki taraf için de avantajlar barındırabilmektedir ama sigorta sahibi olma, emeklilik hakkı, ücretlerdeki eşitsizlikler ve iş güvencesi bakımından çalışanlar açısından hiç de olumlu bir tablo göze çarpmamaktadır (Harvey, 2014, s. 174). Esnek üretim genellikle kapitalizmin acımasız çalışma koşullarından bir kurtuluş, çalışanlar için bir özgürlük umudu gibi görülse de beraberinde getirdiği güvencesizlik olgusu; esnek çalışmanın en tehlikeli boyutlarından biridir.

Güvencesizlik genel anlamda taşeronlaşma, "sözde kendi hesabına" çalışma, yarı zamanlı çalışma, evde çalışma, enformel çalışma gibi tüm çalışma biçimlerinde görülebilmektedir. Fakat güvencesizliğin bu teknik meselelere indirgenmemesi gerekmektedir. Çünkü güvencesizlik kayg1-korku gibi duyguları doğurmakta, özellikle çalışma yaşamında yabancılaşma olgusunun keskin biçimde kendini göstermesine sebep olmaktadır. "Piyasanın esneklik olarak adlandırdığı şeyi çalışanlar gerilim olarak yaşamaktadır (Başçı, 2018, s. 25)." Böylece güvencesizlik; iş dışını, yeniden üretimi, toplumsal yaşamı da kapsamaktadır. Özetle esnek çalışma biçimleri çalışma hayatında meydana getirilen biçimsel ve teknik düzenlemeler olup güvencesizlik tüm bunları da kapsayan ve çalışanların özel hayatlarına sirayet ederek salt somut bir halden çıkıp duygularına dahi yansıyan geniş bir süreci tarif etmektedir (Bilir Kat, 2016, s. 34). Ayrica güvensizlik, piyasalardaki problemler sonucunda istenmeyen durumlar neticesinde ortaya çıkan bir olgu değildir, aksine yeni piyasa sistemleri güvensizliği içine alacak şekilde düzenlenmiştir. Başka bir deyişle, güvensizlik yeni biçimde ortaya çıkan bürokrasinin başına gelen bir şey değildir, tam olarak böyle olması amaçlandığı için meydana gelen bir durumdur (Sennett, 2017, s. 131). Böylece kapitalizm ve piyasa ekonomisi düzeni kendisini güvensizliği yeşerterek geliştirmekte ve sistemin devamlılığını bu sayede sağlamaktadır.

\section{Çağrı Merkezi Çalışanlarının Üretim Süreçleri ve Duygusal Emek}

Çağrı merkezlerinde gerçekleştirilen üretimin temeli insan iletişimine dayanmaktadır ancak aynı zamanda bu iletişim, tamamen insan duygularından arındırılmaktadır. Hizmet sektöründeki duygusal emeğin bu üretimi çoğu zaman birçok açıdan yeni bir vasıf kazanma olarak nitelenmektedir. Çünkü çağrı merkezlerinde çalışabilmek sabır, hoşgörü, nezaket gibi birçok duygusal kriterin yanı sıra bilgisayar kullanma becerisi gibi daha teknik bilgilere hakim olmayı da zorunlu kılmaktadır. Duygular açısından çağrı merkezi çalışanlarından duygularını denetleme becerisine sahip olmaları da beklenmektedir ve bu kişisel duygu denetimi ayrı bir vasıf olarak görülmektedir. Ancak bu noktada artı değer üretimi için geçerli koşulları sağlayan duygusal ve teknik beceriler yani sermayenin vasfi, aslında emeğin vasıfsızlaşması anlamına gelmektedir. Bu vasıfsızlaşma, çağrı merkezlerinde ortaya konan 
emeğin "elinde avucunda bilgi - beceri adına ne varsa parça pinçik edilmesidir (Yücesan Özdemir, 2014, s. 110).” Bu nedenle çağrı merkezleri kalabalık kişilerin yan yana masalarda çalışması, tek tip bir metin üzerinden doğaçlamaya izin verilmeden bir üretimin gerçekleştirilmesi ve böylece hizmet üretiminin standardize edilmiş karakteri gereği bacasız. bir fabrika olarak ele alınabilmektedir.

Ayrıca çağnı merkezlerinde gerçekleştirilen üretim salt bir hizmet üretimi olarak gerçekleşmemektedir, bu hizmet üretimi aynı zamanda toplumsal ilişkileri üreten ve düzenleyen bir alan olduğundan yeniden üretim mekanizmalarına da katkı sağlamaktadır. $\mathrm{Bu}$ açıdan çağrı merkezlerinde gerçekleştirilen üretimin çıktısının "somut" olmamasından kaynaklı olarak bu çalışanların işçi sınıfına dahil edilemeyeceğini ya da hizmet üretiminin bir meta üretimi olmadığını söylemek yanlışa düşmek anlamına gelecektir. Ayrıca çalışanların çalışma hayatlarında deneyimledikleri korku, kaygı, endişe gibi olumsuz duygu durumlarının sebebi sadece telefonun ucundaki müşterinin küfürlerinden, hakaretlerinden veya işverenin mobbinglerinden kaynaklanmamaktadır. Çalışanların bu duygu halleri, piyasanın güvencesizleştirme pratiklerinin bir yansıması olarak çağrı merkezi çalışanlarını sarmaktadır.

Çă̆rı merkezi çalışanlarının güvencesizliğe maruz bırakılma durumu, her bireyin çalışma hayatında sahip olmayı arzuladığı statü ve saygınlık meseleleriyle de iç içedir. Çünkü her birey sevdiği işi yapmak istemektedir ve işini ne kadar severse o kadar sahiplenerek sadakat duygusunu hissetmekte, kendisine olan özgüveni de o ölçüde artmaktadır. Aynı zamanda birey bir işin yapılmasının gerekliliğine ve o işin değerli olduğuna dair ne kadar güçlü bir inanç geliştirirse işin getirdiği bedensel ve zihinsel yorgunluğa o düzeyde katlanabilmekte ve o kadar güçlü bir baş etme stratejisi geliştirebilmektedir. Fakat hizmet sektörünün meydana getirdiği işçi sınıfinın yaşadığı "zulüm” tam olarak burada ortaya çıkmaktadır. Çalışanların yaşamla mücadele edebilmeleri için önce kendileriyle mücadele etmeleri gerekmektedir (Yücesan - Özdemir, 2014, s. 185). Bu mücadele çalışanların kendi Öz saygılarını kaybetmemeye, telefonda işittikleri hakaretlerin şahıslarına değil şirkete yöneltildiğine dair kendilerini ikna etmeye yönelik bir mücadeledir. Bu açıdan çağr1 merkezlerinde standardize edilmiş iletişim yöntemleri, çalışanların saygınlık ve statü kazanmak gibi arzularına ket vurmaktadır. Çalışanlar her sektörde olduğu gibi çağrı merkezlerinde de çalışma hayatları boyunca statü atlamak istemektedir. Bu durumun sebepleri gerek ücret artışı sağlamak gerekse statülerini ve itibarlarını toplum nezdinde arttırmak olarak açılanabilmektedir. Fakat hizmet sektörünün bürokratik basamaklarını tırmanmak, rekabetin yoğun olduğu çağrı merkezlerinde oldukça uzun zamanlar alabilmektedir ve bu sebeple çalışanlar açısından neredeyse bir yaşam biçimine dönüşebilmektedir. Bu nedenle "demir kafes bir hapishaneyse psikolojik bir yuva haline de gelebilmektedir (Sennett, 2017, s. 30).”

Çağrı merkezi çalışanlarının işleriyle ilgili toplumsal saygınlık arzuları, bir sanayi işçisinden birçok açıdan farklılaşmaktadır. Çünkü maddi olmayan emek tartışmalarında da öne çıktığı gibi çă̆rı merkezi çalışanlarının çoğu, bilgi donanımlı bireylerdir ve bu bilgilerinin sayg1 görmesini talep etmektedir. Nasıl ki bir metal işçisinin saygınlık kazanmaya çalışırken hissettikleriyle bir akademisyenin bunu yaparken hissettikleri farkliysa çağrı merkezi çalışanlarının saygınlık kazanma çabalarıyla bir manavın çabası da farklılık arz etmektedir (Sennett ve Cobb, 2018, s. 85). Bu durumun temel sebebi, işin bilgi gerektiren karakterinden kaynaklanmaktadır. Böylece sistem tarafindan rekabet olgusu canlandırılmaktadır. Çünkü sistem tarafindan kendi kendisinin otoritesi olduğu söylenen "bilgi işçileri”, işyerinde hiyerarşik yapılanmayla karşı karşıya kalmaktadır. Aslında kendi 
kendisinin otoritesi söyleminde işveren firsatların herkes için eşit olduğunun altını çizmek istemekte ve çalışanın başarısının ne kadar çaba göstereceğiyle ilişkili olduğunu anlatmayı amaçlamaktadır. Buradaki firsatların eşit olduğu vurgusu, güç eşitsizliğini meşrulaştırmak için ortaya konmuştur ve güç eşitsizliğinin zaten verili bir kural olduğunu ve hayatın her alanında beklendiği üzere rekabetçi toplumun özünü oluşturduğunu açıklamaktadır (Sennett ve Cobb, 2018, s. 251).

Guy Standing, hizmet sektöründeki bu duygusal süreçleri ve insan ilişkilerinin standardize edilmesini "hizmetleşme" olarak ele almaktadır. Hizmetleşme, çalışanların iş tanımının olmaması, iş yerlerinin giderek mekandan bağımsızlaşarak ev içine kayması ve böylece özel alan - kamusal alan ayrımının silikleşmesi, insanların ellerinde bulundurdukları becerileriyle aynı iş için birden fazla sözleşme yapması, mesai saati kavramının fiilen ortadan kalkarak her an her yerde işin gerçekleştirilmesinin beklenmesi gibi tüm esnek istihdam biçimlerini içeren bir durum olarak açıklanabilmektedir. Buradan hareketle hizmetleşmenin, sanayi sektörünün aksine yeni bir denetim sistemi oluşturarak insanların zamanı nasıl kullandıklarına ve nasıl kullanacaklarına odaklandığı bir sistem olduğu söylenebilmektedir (Standing, 2020, s. 71). Bu nedenle çalışanlar esnek çalışma sebebiyle kendileriyle ve yaşamlarıla ilgili herhangi bir plan yapamamaktadır. Çünkü günümüz kapitalizminde her an her şey olabilir mottosu giderek hayatın her alanına yayılmaktadır. Günümüz kapitalizminde bireyler kendi bilgileri, zamanları ve etik anlayışları üzerindeki kontrolü giderek sisteme teslim etmek zorunda bırakılmaktadır. Belirli bir eylemi belirli bir zaman içerisinde gerçekleştirmek, giderek daha az mümkün olmaktadır. Ev aktivitesi olarak görülen birçok eylem, artık iş yerine taşınmaktadır ya da iş yerinde ve mesai saatinde yapılması planlanan işler ev içi hayata taşmaktadır (Standing, 2020, s. 201). Bu durum çalışanların özel hayatlarına da olumsuz etkiler bırakmaktadır. Çalışanlar gün içinde sürekli konuştukları için aileleriyle iletişim kurmak istememekte, sürekli sinirli veya mutsuz müşterilerle iletişimde oldukları için günlük hayatlarındaki olumsuz meselelere tahammül edememekte, insan ilişkilerinde tolerans göstermekte zorlanabilmektedir. Bu durum duygulanımsal emek süreçlerinin, çağrı merkezi çalışanlarının gündelik yaşam pratiklerinde bıraktığı tezahürün yalnızca bir yüzüdür.

\section{Çağrı Merkezlerinde Üretim ve Denetim}

Çağrı merkezlerinde üretimin bilgisayar - telefon - kulaklık üçgeninde gerçekleştirilmesi, çağrı merkezi çalışanları üzerindeki denetleme mekanizmalarını da bu araçların özgül yapılarından dolayı diğer sektörlere göre farklılaştırmaktadır. Çağrı merkezlerindeki üretimin hizmet üretimi olması ürünün kalitesinin ve çalışanların ne kadar zamanda ne kadar üretim yaptığının anlaşılmasını da zorlaştırmaktadır. Aynı zamanda hizmet sektörünün bilgiye ve beceriye dayalı karakteri, bireylerin yapmayı öğrenmiş oldukları şeyi değil yeni bir şey yapabilme yeteneğini ölçmeyi amaçlamaktadır. Böyle bir piyasa sistemi, herkesin kendi kendinin danışmanı olmasını dayatmaktadır. Pratikte bu durum özellikle özel sektöre bağlı çağrı merkezlerinde, şirketin sorumluluğunu azaltmaktadır ve iş ile ilgili herhangi bir aksaklığı çalışanların bilgisizliğine, beceriksizliğine, yeteneksizliğine dayandırmaktadır (Sennett, 2017, s. 75). Böylece çalışanların verimliliklerinin ve çalışanların ürettikleri hizmetin kalitesinin ölçülmesi, şirketler açısından kilit önemde durmaktadır.

Çağrı merkezlerindeki hizmet üretiminin denetimi de içerisinde zaman ile ilgii belirsizlikler barındırmakta ve bu belirsizlikler çalışanların yabancılaşma süreçlerini 
derinleştirmektedir. Öncelikle üretimin bilgisayarlar aracıllğıyla gerçekleştirilmesi bilgisayarın teknik donanımından kaynaklı olarak seslerin kaydedilmesine ve kimi şirketlerin bilgisayarların kameraları aracılığıyla çalışanları çalışma zamanı boyunca gözetlemelerine olanak tanımaktadır. Şirketler üretilen hizmetin kalitesini ve çalışanların verimliliğini bu pratiklerle ölçmektedir. Şirketlerin çalışanlarını bu denli katı mekanizmalarla denetlemesindeki amaç, yeteneği ödüllendirmektir fakat bu denetleme mekanizmalarının bundan daha önemli bir amacı vardır. Bu amaç da "başarısızlığı belgeleyerek meşrulaştırmaktır (Sennett, 2017, s. 81)." Çağnı merkezleri elektronik izleme sistemleriyle tüm çağrıları kayıt altına almakta ve bazen rastgele bazen ise gelen şikayetler veya talepler doğrultusunda belirli bir hedef gözeterek çağrıları dinlemektedir. Çağrıları dinleme işi kalite birimleri denilen bir birim tarafından gerçekleştirilmekte ve bu birimin kriterlerine göre her bir çağrı puanlanmaktadır. Bu puan kriterleri genellikle çağrı merkezi çalışanın standart biçimde söylemesi gereken metnin dışına çıkıp çıkmadığıyla, yasaklı kelimelerin kullanımıyla, müşteriye karşı kullanılan hitap şekliyle belirlenmektedir. Kriterlere uymayan çağrıların olduğu saptandığı takdirde şirket politikalarına göre çalışanların ücretlerinde kesintiler yaşanabilmekte, kalite puanı düşük olan çalışanlar şirkette daha düşük pozisyonlarda görevlendirilebilmekte ya da bir ay boyunca daha fazla mesai ile cezalandırılabilmektedir. Çağnı merkezi çalışanlarının üretim süreçlerinde maruz bırakıldıkları bu denetim mekanizmaları, günümüzün sanayi işçilerini de kapsamaktadır. Özellikle Covid - $19^{4}$ pandemisi döneminde MESS - Safe adı verilen elektronik kelepçe sistemi bu durumun somut örneği olarak sunulabilmektedir. Elektronik kelepçe, işverenlerin işçilerin virüs taşıyıp taşımadığının ölçülmesini sağlayan bir araç olarak sunulmuştur. Ancak sonrasında işverenler, işçilerin fabrikalara giriş - çıkış saatlerinin, mola saatlerinin, servis bekleme saatlerinin, kısaca işçilerin iş süresi boyunca özgürce yapabilecekleri her eylemin bu elektronik kelepçeler sayesinde izlenebileceğini açıklamıştır. Böylece işveren hangi işçilerin kimlerle görüştüğünü ve ne zaman işe gelip ne zaman molaya çıktığını ögrenebilecek ve tüm bunları işçilerin aleyhine kullanabilecektir. Ayrıca bu yöntemin yanı sıra İzole Üretim Tesisleri kurulması fikri de ortaya atılmıştır. İşverenler bu fikirde, bir fabrikada çalışan işçilerin aileleriyle birlikte bir arada yaşayacağı, içinde okuldan hastaneye, kreşten markete tüm ihtiyaçlarını karşılayabilecekleri yapıların bulunacağını açıklamıştır. İşçilerin refahını düşünür görünen bu tesis fikri, işçileri sosyal dünyadan aza etmeyi amaçlayan ve neredeyse işçileri bir çalışma kampına kapatmak isteyen piyasanın yöntemi olarak karşımızda durmaktadır. İşçiler, bu yöntemle "modern pranga"lara bağlanmak istenmiş ve yalnızca fabrikaya gidip işten sonra evine dönen "makineler" haline getirilmeleri hedeflenmiştir (Tekin, 2020). Çağrı merkezi çalışanları açısından doğrudan bir fabrika sistemiyle iç içe olmadıkları için bu yöntemler, birer denetim mekanizması olarak sunulmamaktadır ancak gerek her an kayıt altına alınabilirlikleri gerek iş yeri mekanındaki kameralardan her an izlenebilirlikleri ve bu dinleme - izleme pratiklerinin çalışma hayatlarının son bulmasına dahi sebep olabilmesi, çağrı merkezi

${ }^{4}$ Covid - 19 (Koronavirüs), 2019 yılının Aralık ayında Çin'de ortaya çıkan ve kısa zamanda tüm dünyaya yayılan ölümcül bir hastalıktır. 2020 yılının Mart ayında Dünya Sağlık Örgütü (DSÖ) tarafından "pandemi" olarak ilan edilmiştir. Bu çalışma sürerken Covid - 19 sebebiyle hayatını kaybeden toplam insan sayısı 5,5 milyona yaklaşmaktadır. Türkiye'de ise şu ana kadar 83.075 insan hayatını kaybetmiştir.

5 İzole Üretim Tesisleri kapsamında Çalışma Sosyoloğu Doç. Dr. Hakan Koçak'in röportaj1 için;https:/ / www.evrensel.net/haber/404972/izole-uretim-usleri-ve-elektronik-kelepce-

patron-babalar-prangali-calisma-istiyor 
çalışanlarının denetleme mekanizmalarının özellikle esnek çalışma biçimleri kapsamında oldukça şiddetlendiğini göstermektedir.

\section{Güvencesizleş(tir)me ve Prekaryalaşma Açısından Çağrı Merkezi Çalışanlarının Durumu}

Çă̆rı merkezi çalışanlarının yaşamları parçalanırken yazgılarının birleşmesi durumu, neoliberal piyasa koşullarının getirdiği geleceksizleştirme pratikleri olarak ele alınabilmektedir. Neoliberal piyasadaki esnek çalışma koşulları çalışanların fiziksel çalışma koşullarını esnetmesi, belirsizleştirmesi ve silikleştirmesi açısından çeşitli yabancılaşma süreçlerini meydana getirmektedir ve çalışanlar bu yabancılaşma süreçlerini genel anlamda güvencesizlik olarak deneyimlemektedir. Çünkü hizmet çalışanlarının özellikle kurumsal olmayan ya da çok uluslu bir şirket niteliği bulunmayan iş yerlerinde çalışan kesimi, günümüzde bir sanayi işçisinin yaşayabildiği maaş gününün netliği, mesai ücretlerinin kesinliği, yemek molalarının zamanında kullanımı gibi birçok temel haktan mahrum bırakılmaktadır. Çalışma hayatının içindeki güvencesizlik, burada ortaya çıkmaktadır.

Standing, günümüzde sektör fark etmeksizin birçok çalışanın ortak olarak deneyimlediği yegâne sürecin güvencesizleşme olduğunun altını çizmekte ve yeni tehlikeli bir sınıf olarak bu sinıfa prekarya adını vermektedir. Ayrıca prekarya, "kendisine dayatılan şartlara mecbur olan, alternatif üretme konusunda yetersiz ve örgütsüz olan ve bu çerçevede seçenekleri ellerinden alınan, bir kariyer planı ya da amacı olmayan, sadece günü kurtarma odaklı bir bakış açısına sahip, köksüz, kendisine, doğasına ve emeğine yabancı, umutsuz bir sınıf' olarak da tanımlamaktadır (Kızıltaş, 2019, s. 93). Prekarya homojen bir yap1 arz etmemektedir ve geçici işlerde çalışanları, göçmenleri, mevsimlik işçileri, ev içi bakım hizmetlerinde çalışanları, çocuk işçileri, engellileri ve daha birçok iş sahasında çalışan bireyleri kapsamaktadır. Ancak bu homojen olmama durumuna karşın prekaryaya dahil olan tüm kesimlerin belirleyici ortak özelliği güvencesizlik ve geçiciliktir (Standing, 2020, s. 3133). Standing, prekaryaya giderek daha fazla sayıda dahil olan ve prekaryanın deneyimlemek zorunda bırakıldığı tüm süreçleri gerek çalışma hayatında gerekse gündelik yaşam pratiklerinde barındıran bir grubun da çağrı merkezi çalışanları olduğunu belirtmektedir. "Her yerde karşımıza çıkan çağrı merkezi çalışanları, küreselleşmenin, elektronik hayatın ve yabancılaşmış emeğin sembolüdür (Standing, 2020, s. 35).” Bu yabancılaşmış emeğin temel nedeni de çağrı merkezi çalışanlarının bir yandan eğitimli olmaları diğer yandan ise bu emeklerinin kullanımının şirket ve yaptıkları iş açısından değersiz addedilmesidir. Bu ikili süreç, çalışanların hayatında kendisini huzursuzluk olarak göstermektedir. "Örneğin, güvencesizler nerede iş bulabilirlerse oraya taşınmaya ve bütün hayatlarını ona göre değiştirmeye hazır olmak zorundadır. Bu durum emek güçlerinin sadece üretim alanında değil, yeniden üretim alanında da denetim altına alınması anlamına gelmektedir (Oğuz, 2011, s. 10).” Bu nedenle çağrı merkezi çalışanları sinirli bir ruh haline sahip olmaktadır fakat bu sinirlilik hali genellikle pasif bir durum arz etmektedir. "Prekaryalaşmış zihin korkudan beslenmekte ve korkuyla motive olmaktadır (Standing, 2020, s. 42)." Bu korkuyla motive olma hali, çağrı merkezi çalışanlarında kovma tehdidiyle kendini somutlaştırmaktadır. Kovulma tehdidi altında çalışan çağrı merkezi çalışanları daha çok satış yapmak ve daha "kaliteli” çağrılar gerçekleştirmek zorunda kalmaktadır.

Çağrı merkezi çalışanlarının prekaryalaşma süreçlerindeki bir diğer önemli nokta da çağnı merkezi çalışanlarının meslek içi eğitimlere değil, meslek için eğitimlere tabi 
tutulmasında yatmaktadır (Standing, 2020, s. 205). Çağrı merkezi çalışanları duygularını yönetmek, olumsuz çağrılara olumlu yanıtlar verebilmek ve çağrıları mümkün olduğu kadar en başarılı şekilde yönetmek için çeşitli eğitimler almaktadır. Bu eğitimler çalışanların çalışma hayatlarının verimliliğini arttırmak için düzenleniyor görülse de bu eğitimlerdeki gizli amaç, çalışanların duygusal emeklerinin yönetiminin şirkete yansıyabilecek en az zararla atlatılabilmesiyle açıklanmaktadır. Bu durum çağrı merkezi çalışanlarının mesleklerine yönelik sayg1 duyamamalarına, yaptıkları mesleğin toplum ve birey nezdinde değerli olmadığına kanaat getirmelerine sebep olmaktadır. Bu kapsamda Standing, prekaryalaşmanın çalışanlar açısından herhangi bir mesleki gelişim hissi olmaksızın performansa dayalı bir hayat biçimi anlamına geldiğini savunmaktadır (Standing, 2020, s. 219-220). Çağrı merkezi çalışanları bu durumla başa çıkma stratejilerini ise var olan psikolojik sermayelerinin birikimlerine göre geliştirmektedir. Çünkü psikolojik sermaye, durum ve şartlara göre değişkenlik gösterebilmektedir ve çalışanların performanslarını yönlendirebilmelerini sağlayan bir araç rolü üstlenebilmektedir (Biçkes ve diğerleri, 2014, s. 98). Ayrıca çağrı merkezi çalışanlarının da hizmet sektörünün genelini kapsayan bu olumsuz durumlarla başa çıkma stratejilerinden bir diğeri, yeni işlerin icadı olarak ele alınabilmektedir.

Günümüz kapitalizminde ve neoliberal piyasa koşullarında gerçekten yeni işlerin icat edilip edilmediği meçhul bir noktada dursa da işlerin isimlerinin karmaşıklaştığı, genellikle işin ismiyle içeriğinin nitelik açısından uyuşmadığı somut bir gerçekliktir. Bu yeni işlerin icadı, günümüz kapitalizminin meslek algısını dönüştürmesiyle doğrudan ilişkilenmektedir. Geleneksel piyasa koşullarında meslekler, sabit ve kararlı yapılar olarak kodlanmaktadır. Bu açıdan meslekler, bireylerin hayatlarında kararlığ1 simgeleyerek "ömür boyu bir proje" karakteri taşımaktadır ve meslek değiştirmek gerek yeni işe uyum sağlamak gerekse alışılmış yaşam biçimlerini terk etmek açısından oldukça zor bir seçim olmaktadır (İlhan, 2008, s. 318). Ancak günümüz kapitalizminin dayattığ1 esnek ve akışkan iş yapıları, bireylerin katı ve sabit meslek algılarını ortadan kaldırmaktadır. Bireylerin böyle bir çalışma hayatında hızlı ve ani değişimlere ayak uydurabilmeleri, kısa vadeli planlar yapmaları ve ana odaklanmaları beklenmektedir. Bu beklentiler, bireylerin kurgusal mesleki hareketlilik çabalarında kendini göstermektedir. Kurgusal mesleki hareketliliğin somutlaşması, birtakım unvanların ya da doğrudan meslek isimlerinin "havalı" biçimlerde adlandırılması şeklinde gerçekleşmektedir (Standing, 2020, s. 37). Kariyer anlamında hiçbir yere oturmayan ya da yukarlya doğru sınıfsal hareketlilik açısından hiçbir geleceği bulunmayan mesleklere, mesleklerin niteliğinden bağımsız olarak "havalı" isimlerin verilmesi, o işin güvencesiz yanını maskelemektedir. Temizlik görevlisine "hijyen danışmanı” denmesinde görüldüğü gibi bu adlandırmalar, bu mesleği yapanlar açısından farklı anlamlar taşıyabilmektedir fakat emek süreçlerinde hiçbir değişiklik yaşanmamaktadır (Standing, 2020, s. 101). Bu değişikliğin yaşanmamasının temel sebebi ise gerek mesleklerin adları "havalı" versiyonlarıyla değiştirilsin gerek bu versiyonlar sayesinde çalışanların güvencesiz ve esnek istihdam edilebilirlikleri gizlenmeye çalışılsın günün sonunda sınıfsal açıdan önem arz eden nokta, üretim ilişkileridir.

Mesleklerin bu denli kaygan ve stabil olmayan yapısı, çalışanlar açısından etik bir boşluk da yaratmaktadır. Bu etik boşluk, çalışanların duygu durumlarına doğrudan etki etmekte ve çalışma yaşamlarındaki duygusal - duygulanımsal emek sarfiyatlarını derinleştirebilmektedir. Bu etik boşluk, insanların kendilerine sayg1 duyamamasına, yaptıkları işin de toplumsal açıdan değer arz etmemesine sebep olmaktadır (İlhan, 2008, s. 
117). Çalışanların ve yapılan işin bu değersizleşme süreci, çalışanların toplumsal hafızalarını geliştirememelerine de yol açmaktadır. Bireyler kendilerini yaptıkları iş ile tanımlayamamakta, bir toplumsal gruba aidiyet hissedememektedir. Toplumsal hafiza geliştirmenin çalışanlar açısından en olumlu yönü, etik kuralların varlığından kaynaklı olarak duygusal açıdan istikrar sağlamasında yatmaktadır. "Toplumsal hafiza biz ne olmayı arzuluyorsak ona göre genişler ama arzularımızın önünde de birtakım toplumsal engeller mevcuttur. Örneğin birçok toplumda bankacı ya da avukat olmak istediğini söyleyen bir işçi sınıfı çocuğuna gülünürken; muslukçu ya da kuaför olmak isteyen bir orta sınıf çocuğuna da sert gözlerle bakılır. Olmadığın şeyi yapamazsın. Kendimizi ne olduğumuz ve ne olamayacağımız ya da ne olabileceğimizin yanında ne olmadığımızla da tanımlar ve ifade ederiz. Prekarya kendi başına var olmaz; aynı zamanda ne olmadığıyla da tanımlanır (İlhan, 2008, s. 119-120).” Bu açıdan çağrı merkezi çalışanlarının kendilerini toplumsal ilişkilerinde "müşteri temsilcisi" olarak değil de "bankanın iletişim uzmanı" olarak tanıtmaları, saygı duyulma arzularıyla ilişkilenmektedir. Bu noktada mesleki aidiyet hissinin zayıflaması, çağrı merkezi çalışanlarının örgütlenme pratiklerinin bölünmesini de beraberinde getirmektedir. Çünkü tüm çağrı merkezi çalışanlarının hem mesleklerini hem de kendilerini bu mesleklerin içinde konumlandırdıkları yeri farklı biçimlerde tanımlamaları, örgütlenme olanaklarını daraltmaktadir.

\section{Yöntem}

$\mathrm{Bu}$ makale çağnı merkezi çalışanlarının çalışma koşullarının çalışanların duygusal emek süreçlerini hangi biçimlerde etkilediğini araştırmayı hedeflemektedir. Bu doğrultuda araştırma nitel araştırma modeliyle yürütülmüştür. Araştırma kapsamında 24 çağrı merkezi çalışanı ve çağnı merkezi iş kolunda faaliyet gösteren 2 sendika yetkilisiyle yarıyapılandırılmış derinlemesine görüşmeler ve odak grup görüşmeleri gerçekleştirilmiştir. Araştırmanın katılımcıları e-ticaret, telekomünikasyon ve bankacılık olmak üzere 3 sektörde çalışmaktadır. Odak grup görüşmeleri ise biri bankacılık sektöründe çalışan 5 katılımcı biri ise telekomünikasyon sektöründe çalışan 6 katılımcıdan oluşmak üzere 2 kere gerçekleştirilmiştir. Araştırma kapsamında elde edilen bulgular katılımcıların yaş, eğitim durumu ve gelir düzeyi açısından farklılık sunmamaktadır. Yalnızca özellikle çalışma hayatındaki toplumsal cinsiyete dayalı iş bölümü ve pandemi sürecinin özgüllükleri nedeniyle cinsiyet açısından farklılığa rastlanmıştır. Bu açıdan araştırma kapsamında kadın çalışanların erkek çalışanlara nazaran duygusal emek süreçlerinin olumsuzluklarına daha fazla maruz kaldıkları söylenebilmektedir. Tüm katılımcıların demografik özellikleri Tablo 1 'de sunulmaktadir.

Araştırmada gerçekleştirilen görüşmeler sonucunda elde edilen veriler not alma ve kodlama tekniğiyle kategorilere ayrılarak analiz edilmiştir. Analizin sonucunda elde edilen verilere göre ortaya çıkan üst temalar kapsamında bulgular yorumlanmıştır. Araştırma kapsamında katılımcıların kişisel bilgilerinin saklanması ve gizliliklerinin sağlanması amacıyla her katılımcıya isimlerinden farklı rumuzlar atanmıştır. Bulgular yorumlanırken bu rumuzlar kullanılmıştır. 
Tablo 1. Katılımcıların Demografik Özellikleri

\begin{tabular}{lllll}
\hline Rumuz Yaş & Şehir & Eğitim Durumu & Gelir Düzeyi \\
\hline Yasin & 30 & Batman & Üniversite Mezunu & $2825 \mathrm{TL}+$ prim \\
Duygu & 24 & Edirne & Üniversite Mezunu & $2825 \mathrm{TL}+$ prim \\
Sevgi & 27 & Ankara & Üniversite Mezunu & $3000 \mathrm{TL}$ \\
Hacer & 23 & Balıkesir & Üniversite Öğrencisi & $2825 \mathrm{TL}+$ prim \\
Hale & 25 & Ankara & Üniversite Mezunu & $3300 \mathrm{TL}$ \\
Ayça & 25 & Ankara & Üniversite Mezunu & $2825 \mathrm{TL}$ \\
Bilge & 25 & Ankara & Üniversite Mezunu & $2825 \mathrm{TL}+$ prim \\
Güzide & 26 & İzmir & Üniversite Mezunu & $3500 \mathrm{TL}$ \\
Ö.Efe & 32 & Ankara & Doktora Öğrencisi & $3000-3500 \mathrm{TL}$ \\
Uraz & 24 & Ankara & Üniversite Mezunu & $2825 \mathrm{TL}+$ prim \\
Emre & 26 & İstanbul & Üniversite Mezunu & $5000-5500 \mathrm{TL}$ \\
Zuhal & 24 & Batman & Üniversite Mezunu & $2825 \mathrm{TL}+$ prim \\
Selma & 39 & Ankara & Üniversite Mezunu & $2825 \mathrm{TL}$ \\
Gamze & 27 & Ankara & Üniversite Mezunu & $3500 \mathrm{TL}$ \\
Behçet & 34 & Düzce & Üniversite Mezunu & $2825 \mathrm{TL}+$ prim \\
Murat & 37 & Eskişehir & Üniversite Mezunu & $2825 \mathrm{TL}+$ prim \\
Ufuk & 31 & Ankara & Lise Mezunu & $3000 \mathrm{TL}$ \\
Elif & 24 & Ankara & Üniversite Mezunu & $2825 \mathrm{TL}+$ prim \\
Zafer & 23 & Ankara & Üniversite Mezunu & $2825 \mathrm{TL}+$ prim \\
Koray & 24 & Ankara & Üniversite Mezunu & $2825 \mathrm{TL}+$ prim \\
Burak & 24 & Ankara & Üniversite Mezunu & $2825 \mathrm{TL}+$ prim \\
Burçin & 31 & Düzce & Lise Mezunu & $2825 \mathrm{TL}+$ prim \\
Arif & 29 & Van & Önlisans Mezunu & $2825 \mathrm{TL}$ \\
Tülay & 28 & İzmir & Üniversite Mezunu & $2825 \mathrm{TL}$ \\
& & & &
\end{tabular}

\section{Bulgular}

Araştırmanın bulguları açıklanırken duygusal emek perspektifine odaklanılarak öncelikle çalışanların çalışma koşullarının ortaya konması açısından çağrı merkezlerinde esnek çalışmanın yansımaları üst temasına değinilecektir. Sonrasında çağrı merkezi çalışanlarının duygusal emek sarf etmelerinin çalışma koşulları ile olan ilişkisi çağrı merkezlerinde mobbingin görünümleri üst teması içerisinde açıllanacaktır. Son olarak pandemi sürecinin çağrı merkezi çalışanlarını ne ölçüde etkilediği çağrı merkezlerinin pandemisi üst teması içerisinde tartışılacaktır.

\section{Çağrı Merkezlerinde Esnek Çalışmanın Yansımaları}

Çağrı merkezlerinde gerçekleştirilen üretimin özellikle neoliberal istihdam politikaları göz önünde bulundurulduğunda giderek esnekleşmesi ve çalışanların mesai saati algıları başta olmak üzere çalışma hayatlarına dair zaman-mekan algılarının giderek silikleşmesi, çalışanlarda "robotikleşme”, "stres", "kaygı" gibi birçok olumsuz duruma sebep olmaktadır. 
Gerçekleştirilen üretimin doğrudan insan iletişimine dayanması ve müşterilerin bir nevi patron işlevi gütmesi de çağrı merkezi çalışanlarının bu olumsuz duygularını pekiştirmektedir.

Çağrı merkezlerinde hizmet üretiminin doğrudan insan iletişimine dayanması çağrı merkezi çalışanlarının çalışma hayatında çeşitli duyguları kullanmasını ya da kullanamamasını beraberinde getirmektedir. Çalışanların çalışma süresi boyunca belli duygularını göstermek, belli duygularını ise saklamak durumunda kalabilmektedir. Robotikleşme ve duygusal yıpranma üst teması bu bağlamda çağnı merkezlerindeki üretimin standardize edilmiş yapısına vurgu yapmaktadır. Araştırma kapsamında katılımcılara çalışma hayatlarında duygularını yansitıp yansitamadikları sorulduğunda duygulara izin verilmediğini, aksine kendilerini "robot" gibi hissettiklerini belirttikleri görülmektedir:

"Her şey robotik, kendimi insan gibi hissetmiyordum. Duygu hissetmiyordum bile. Bütün hepsini sömürüyorlar. Günde 500 çağrn almak insanüstü bir şey.” (Duygu, Derinlemesine Görüşme, 2021)

"Çağnı merkezinde çalışmak duygulara yer verilen bir şey değil. Senin duygularına yer yok. Müşteri veriyor, sen veremiyorsun. Robotlaşmaya başladım diyorum iyice.” (Hale, Derinlemesine Görüşme, 2021)

Çağrı merkezi çalışanlarının 8 saat ve bu saate ek mesai saatleri boyunca belli bir metin üzerinden gerçekleştirdikleri iletişim biçimleri ve bu iletişim boyunca müşteriden gelen olumlu veya olumsuz tüm tepkilere karşı aynı cevapları vermelerinin gerekliliği çalışanlarda robota dönüştükleri hissini uyandırmaktadır. Çalışma süresi boyunca aynı cümleleri tekrarlayan, bilgisayarda veya telefonda aynı tuşlara basan çağrı merkezi çalışanları, herhangi bir yaratıcı eylemde bulunmadıklarını ve bu yüzden kendilerinin makineleştiklerini belirtmektedir:

"Duygusalım ama insanı makine yapıyorlar. Sadece çalış, mesaini doldur. Insanlar çaresiz ama size yardım ettirmiyorlar. Bu kadar paraya bu değer mi?” (Zafer, Odak Grup Görüşmesi, 2021).

Çağrı merkezi çalışanlarının deneyimlediği duygusal emek süreçleri çalışanlarda kısa ve uzun vadede güvensizlik, geleceksizlik, stres gibi birçok olumsuz ruh haline de yol açmaktadır. İş yerinde sürekli standardize bir iletişim kurmak zorunda kalan çalışanlar, özel yaşamlarındaki ilişkilerinde tahammülsüzlüğe kapılmakta, uzun cümleler kurmak ve yakınlarıyla iletişim kurmakta zorlanabilmektedir.

Katılımcılara çalışma hayatlarında sarf ettikleri duygusal emek süreçlerinin özel yaşamlarına etkisi olup olmadığı sorulduğunda katılımcıların yoğun iş yükleri ve çalışma esnasında konuşmak için sarf ettikleri yoğun efor nedeniyle özel yaşamlarının olumsuz biçimde etkilendiği görülmektedir:

"Bu işe başladığımdan beri arkadaşlarımla telefonda konuşamıyorum." (Güzide, Derinlemesine Görüşme, 2021)

"İnsanlara açıllama yapmak istemiyorum." (Gamze, Derinlemesine Görüşme, 2021)

"Çağnı merkezinde çalışan insanların ekstra bir sosyal hayatlarının olması gibi bir şey söz konusu değil. Bir insanın günde 8 saat birileriyle iletişim halinde olduğunu düşünün, geriye kalan zamanlarında aileleriyle, eşleriyle, dostlarıyla konuşabilecekleri hiçbir şey kalmıyor. Bir arkadaşım nasıl 
olduğumu sormak için beni arıyor, ben ise hep iş yerinde yaşadığım şeyleri anlatıyorum.” (Arif, Derinlemesine Görüşme, 2021)

"Sosyal hayatımdan insan çıkartmaya başladım. Kardeşlerim, yakın arkadaşlarım aradığında telefonu açmaya da korkuyorum. Sonrasında yüz yüze de istememeye başladım. Sanki gün içinde 200 kişiyle görüşmüşüm ve ekstra kimseyle görüşemezmişim gibi.” (Murat, Odak Grup Görüşmesi, 2021)

Çağrı merkezi çalışanlarının deneyimlediği duygusal emek süreçlerinin bir diğer yansıması ise çalışanların kendilerini toplumsal açıdan değersiz hissetmeleridir. Duygusal olarak oldukça yoğun biçimde yıprandıklarını, sürekli konuştukları için ses tellerinden kaynaklanan rahatsızlıklar yaşadıklarını belirten katılımcılar, karşılığında hem emeklerinin karşılığını almadıklarını hem de gerekli değeri görmediklerini aktarmaktadır:

"Sanki sen doğa üstü güçlere sahipmişsin gibi düşünüyorlar. Maalesef kelimesi olumsuz duygu diye yasakl. Sanki senin elinde sihirli bir değnek varmış gibi davrantyorlar. İlk zamanlar kabus gibiydi." (Bilge, Derinlemesine Görüşme, 2021)

"Karşındaki insan seni insan olarak görmüyor. Hayır dediğimiz anda yokuz.” (Behçet, Odak Grup Görüşmesi, 2021)

Katılımcıların aktardıklarından görüldüğü üzere çağrı merkezlerinde gerçekleştirilen üretimin masa başında gerçekleştirilmesi ya da sadece telefonla konuşarak hizmet verilmesi çalışanların çalışma hayatlarını kolaylaştırmamakta, aksine çalışanların psikolojik olarak yıpranmalarına yol açmaktadır. Hizmet sektörünün birçok alanında çalışan bireyler tarafından deneyimlenen stres, gerginlik, güvencesizlik ve yabancılaşma gibi olgular çağnı merkezi çalışanları açısından da geçerliliğ̈ini korumaktadır.

\section{Çağrı Merkezlerinde Mobbingin Görünümleri}

Mobbing olgusu, günümüzde tüm çalışma hayatının içine yayılan bir karaktere bürünmüş görünmektedir. Tüm mesleklerde farklı biçimlerde kendini göstermektedir fakat hangi meslekte olursa olsun bir işyeri şiddeti olarak tanımlanmakta ve çalışanların psikolojik ve duygusal açıdan oldukça yıpranmasına sebep olmaktadır. Çalışma yaşamında mobbing genellikle yıldırma, psikolojik baskı, yok sayma, aşağılama, değersiz hissettirme gibi psikolojik şiddet biçimlerinde varlık göstermektedir. Bu bağlamda mobbing çalışanları birçok olumsuz yönde etkilemektedir. Mobbinge uğrayan çalışanlar çaresiz hissetmekte, kendilerini değersiz görmekte, yeteneksiz olduklarını düşünmekte ve psikolojik olarak bunalım yaşamaktadır. Ayrıca mobbing çalışanlarda anksiyete, depresyon, panikatak gibi psikolojik rahatsızlıklara da sebep olabilmektedir (Çukur, 2016). Bu nedenle mobbinge dair hukuksal düzenlemelerin yapılması ve bu yönde denetlemelerin yeterli biçimde gerçekleştirilmesi önem taşımaktadır.

$\mathrm{Bu}$ doğrultuda çağr1 merkezlerinde mobbingin görünümleri üst temasinda katılımcılara çalışma esnasında işverenler, takım liderleri ya da müşteriler tarafından olumsuz davranışlara maruz kalıp kalmadıkları sorulmuş ve araştırma kapsamında mola gaspının, çağrı merkezi çalışanlarının çalışma süresi boyunca karşılaştıkları en sık mobbing biçimi olarak ifade edildiği görülmüştür. Mola gaspı hakkında katılımcılar yasal mola sürelerini kullanamadıklarını, molalar esnasında sözlü uyarı alabildiklerini, bilgisayar başında geçirmedikleri bir dakikanın bile şirket tarafından hesabının tutulduğunu belirtmektedir: 
"İşyerinde çalışırken kapıda bekliyorlardı molaya çıkamazsınız diye. Tehditler kendi ellerinde hem içeriden hem kalitecilerden. Mobbing olmaz mi? Rotasyon tehdidi olabiliyor. Çağnı merkezlerinin karakteri mobbing." (Behçet, Odak Grup Görüşmesi, 2021)

"Mesaiye birakıyorlar ama ücretini ödemiyorlar. Buna itiraz ettiğimde takım liderim beni istifaya zorladı. Çünkü beni kendisi çıkarsa tazminat ödemek zorunda kalacak." (Tülay, Derinlemesine Görüşme, 2021)

"Vardiyalı çalışırken akşam 5’te başlayan vardiya için hatta girmeden bir yemek molanı ve 10 dakikalık bir diğer molanı kullandırıyorlar. Ben işe yeni başlayacağım, daha acıkmadım ki neden yemek molamı kullanayım? Çünkü molalar sistem tarafindan otomatik belirleniyor. Sen zaten işe başlamadan bir molanı ve yemek molanı kullanmış oluyorsun. Sonra 2 saat 45 dakika ara vermeden çalışmak zorundasın.” (Burak, Odak Grup Görüşmesi, 2021)

Çağrı merkezi çalışanları açısından mola gaspı biçiminde uygulanan mobbing, çalışanların bedensel ve zihinsel yorgunluklarını da artırmaktadır. Çok kısa zamanda çok fazla çağrı almaları beklenen çalışanlar, dinlenebilmek için molalarını da tam anlamıyla kullanamamakta ve bu sebeple gerek ses tellerinden gerekse kulaklarından kaynaklı birçok rahatsızlık yaşamaktadır. Çalışanlar doğrudan bedensel aktivitelerinde dahi uğradıkları mobbingin etkilerini hissetmektedir:

"Satıştan dolayı mobbing oluyor. Vücudumdaki sinir uçlarının gerildiğini hissettim.” (Elif, Derinlemesine Görüşme, 2021)

"Sürekli florasan lambanın altında çalışmak, güneş görememe sorunu... Depresifleştiriyor bu durum. Sese karşı duyarsızlaşma, duyma problemleri de oluyor. Bu yüzden ücretsiz izne çıkanlar oldu. Sosyalleşemedim uzun süre. Bir yandan sosyalleşmeye açtım ama canım istemedi. Rüyamda da birileriyle konuşuyordum. Günlük konuşmalarıma da yansıyordu." (Uraz, Derinlemesine Görüşme, 2021)

"Motivasyon adı altında mobbing var. Kardeşiz, biz bir aileyiz diyorlar. Bunları tatsızlık çıkmasın diye söylüyorlar ama çalışanlar sindirmek için olduğunun farkında değil.” (Yasin, Derinlemesine Görüşme, 2021)

"Bunu yaşamadığın herhangi bir gün olmasına imkan yok. Yazılı uyarı veriyorlar performans düşükse. Savaş alanı düşün alanın ortasına bizi atmişlar.” (Ufuk, Derinlemesine Görüşme, 2021)

"Kabloyla hareket zor, yerinde durmak zorundasın. Ayağa kalkınca kızdıkları da oluyordu." (Duygu, Derinlemesine Görüşme, 2021)

Araştırma kapsamında katılımcılara çalıştıkları işin olumsuz yönleri sorulduğunda çalışanlar bu olumsuzlukları sürekli kayıt altında olmaları ve kota doldurma baskısı şeklinde belirtmiştir. İşveren bağlı olduğu firmaya belirli bir kotada satış yapılacağının teminatını verdiği için çalıştırdığı müşteri temsilcilerine de bu kotayı doldurma baskısı yapmaktadır. Ancak satış odaklı işlerin gerçekleştirilmediği, yalnızca toplumsal yeniden üretimi sağlayan bir hizmet üretiminin yapıldığ sektörlerde de mobbing, satış odaklı işlemlerin gerçekleştirildiği iş kollarını da kapsamakla birlikte doğrudan "kaliteli çağrı almak" anlamına gelmektedir. 
Kaliteli çağrı almak çağrı merkezlerinde müşteri temsilcisinin belirlenen söz kalıplarına uygun biçimde konuşmasını, müşterinin sorununu veya isteğini mümkün olan en kısa zamanda halledebilmesini, müşteriye söylemesi gereken bilgileri eksiksiz aktarmasını, yanlış bir bilgi aktarımında bulunulmamasını ifade etmektedir. Çağrı merkezlerinde görüşmelerin "kalite standartları gereği” kayıt altına alınması, bu durumun kontrolü için gerçekleştirilmektedir. Böylece çalışanlar şirket tarafindan denetlenmektedir. "Kalite standartları gereksinimi” bu anlamıla şirketin çalışanları denetleme gereksinimini ifade etmektedir. Alınan çağrıların kalitesi, çağrı merkezlerinde "kalite birimi" olarak tanımlanan birimler tarafindan gerçekleştirilmektedir. Genellikle her çalışanın her ay için birkaç çağrısı rastgele seçilerek dinlenmekte, dinlenen çağrılar 100 puan üzerinden puanlanmaktadır. Puanı yüksek bulunan çalışanlar primler ile ödüllendirilmektedir. Ancak çalışanlar gerek prim alma konusunda gerekse çağrılarının dinlenme ve puanlanmaları konusunda haksızlığa uğradıklarını düşünmektedir. Bu haksızlıklar müşterilerden de kalite birimindeki çalışanlardan da kaynaklanabilmektedir:

"Bizim firmamız kurumsal olduğunu iddia ediyor ama biz kurumsalın da merdiven altıyız. Kalitemiz düşük geliyor, bize deneyimlisiniz nasıl bu hataları yaparsınız diyorlar. Ama bugün işe alınan insanla aynı haklara sahibim, neyin deneyiminden bahsediyorlar? İşimi seviyorum ama hakkımı almak istiyorum.” (Burçin, Odak Grup Görüşmesi, 2021)

"İşten çıkarılma yok ama iyi satış yapamazsan ücretsiz izne çıkarıyorlar. 'Çık, git, akıllan gel’ gibisinden. 600 kişiden 300'ü işten çıktı, 150’si de ücretsiz izinde." (Zuhal, Derinlemesine Görüşme, 2021)

Çalışanların çağrılarının rastgele dinlenmesi ve bu dinlemeler üzerinden denetlenmesi, çalışanların üzerindeki kontrol mekanizmasını her an hissetmelerine sebep olmaktadır. Bu nedenle çalışanlar üzüldükleri, empati kurdukları, yardım etmek istedikleri müşterilere karşı duygularını yansıtmaktan çekinmektedir. Bu durum da çalışanların çalışma yaşamlarındaki duygusal emek süreçlerini derinden etkilemektedir. Çünkü çalışanlar hem çalışma süresi boyunca yalnızca belirlenmiş ve standardize edilmiş duyguları gösterebilmekte hem de telefonun ucundaki müşteriye yardım edemeyince ya da duygularını özgürce yaşayamayınca karakterlerinden ödün veriyormuş gibi hissederek duygusal uyumsuzluk yaşamaktadır.

Katılımcılara çalışma koşullarının olumsuzluğunun yanı sıra bu koşulların değiştirilmesi için çalışma arkadaşlarıyla nasıl bir ilişki içinde oldukları, sendikalı olup olmadıkları ve eğer değillerse sendikalaşma konusunda ne düşündükleri sorulduğunda katılımcılardan 3’ünün sendikayı olumlu bulduğu görülmüştür:

"Sendikal anlamda denetleme yok. Patronun doyumsuz bir yanı vardır her zaman.” (Uraz, Derinlemesine Görüşme, 2021)

"Minimum ücret, minimum mola. Beklenen performans maksimum. 75 dakika toplam molamız var. Yemeğe çıkamadığımız oldu. Sendika bekliyoruz bunların çözümü için.” (Burçin, Odak Grup Görüşmesi, 2021)

"Takım liderleri sendika faaliyetleri için 'senin yaptığını biliyoruz ama kanitlayamiyoruz' dediler. Sonra 'bizden ne istiyorsun' diye sordular. Ben de 'bugüne kadar ne verdiniz ki, ben buraya sendikayı sokacağım' dedim. Bir sınıfa ait hissedelim diye bu çabamız.” (Behçet, Odak Grup Görüşmesi, 2021) 
24 katılımcıdan yalnızca 3’ünün sendikaya ve genel anlamda örgütlenme ve dayanışma göstermeye dair olumlu tavır, çağrı merkezlerinde bürokratik kısıtlamalar nedeniyle örgütlenme olanaklarının daraldığını ve çalışanların sendika ile bir çözüme kavuşacaklarına dair inançları olmadığını göstermektedir. Araştırma kapsamında görüşülen bir sendika çalışanı da bu durumu doğrulamaktadır:

"Ülke ekonomisiyle ilişkili olarak çalışanlar aslında işçilik kimliklerinin farkında oluyorlar. Ama 'hele bir herkes sendikalı olsun da...' diyorlar." (Cengiz, Sendika Çalışanı, Derinlemesine Görüşme, 2021)

"Çağrı merkezleri birçok farklı iş kolu içinde gösterilebildiği için işverenler sendikalaşmanın önüne geçebilmek amacıyla çalışanlarını farklı işkollarında gösterebiliyor. Bu durum da bizim faaliyet alanımızı kısıtlıyor. Baktı̆̆ımızda çalışanların farklı iş kollarına bağlı olduğunu görüyoruz ve belirli sayıyı yakalayamadığımız için o şirkette sendikal faaliyet yürütemiyoruz." (Ersin, Sendika Çalışanı, Derinlemesine Görüşme, 2021)

\section{Çağrı Merkezlerinin Pandemisi}

Covid-19 pandemisi dünyada ve Türkiye'de yayılmaya başladığı günden bu yana ekonomik, siyasal ve toplumsal açıdan birçok olumsuzluğu beraberinde getirmiştir. Ekonomik açıdan temel ihtiyaçların üretimi dişında üretim yapan birçok sektör pandemi süreci nedeniyle birçok zorlukla baş etmek zorunda kalmıştır. Ancak özellikle hizmet sektörünün yeme-içme kategorisi dışındaki kamu hizmeti, e-ticaret, telekomünikasyon gibi alanlarında faaliyet gösteren şirketler, pandemiyi kendi lehinde kullanarak şirket kârlarını arttırmıştır. Özellikle pandemi sürecinde internet alışverişinin artması, bu sektörlerin kârlarının artmasına olanak tanımıştır. Fakat bu sektörlerin kâr artışının tek nedeni talebin artması değil aynı zamanda hizmet sektörünün diğer sektörlere nazaran evden (uzaktan) çalışmaya daha kolay biçimde adapte olmasını sağlayan karakteridir. Çağrı merkezleri gibi bilgisayar bazlı üretimin gerçekleştirildiği hizmet sektörlerinin çoğunda pandemi süreci evden çalışma biçiminde gerçekleştirilmiştir. Evden (uzaktan) çalışma yönetmeliğine göre işveren evden çalıştırdığı tüm çalışanlara, işyerindeki koşulları sağlamakla mükellef kılınmaktadır ve evden çalışma kararının alınmasında işçilerin onayı da aranmaktadır ${ }^{6}$. Fakat bu noktadaki denetim yetersizlikleri veya yönetmelikteki çeşitli boşluklar, işverenler tarafindan çalışanları sömürmenin bir aracı olarak kullanılmaktadır. Bu durum da çağnı merkezi çalışanlarına yabancılaşma, özel hayat - çalışma hayatı ayrımının ortadan kalkması gibi çeşitli olumsuzluklar biçiminde yansımaktadır.

Katılımcılara pandemi sürecinde evden çalışma sistemine geçişi nasıl değerlendirdikleri sorulduğunda katılımcıların duygusal açıdan yıprandıkları ve hak gasplarının arttı̆̆ görülmektedir:

"Sadece internetin bir kısmını karşılıyorlar. Mesai oluyorsa şirkette ikinci yemek hakkın olurdu. Evde bu ödenmiyor. Geçtiğimiz yıl 35 lira elektrik ödüyordum bu sene 120 lira oldu. Doğalgaz da öyle. Benim avantajım evimin büyük olması ama biz 600 çalışanız. \%80’i kalabalık aileleriyle yaşıyor. 80 kişiyiz bir operasyonda 30’u ücretsiz izne çıkartıldı. Ama hat yoğun diye hatta 610 Mart 2021 tarihinde Resmi Gazete'de yayınlanan 31419 sayılı Uzaktan Çalışma
Yönetmeliği için bknz.: https://www.resmigazete.gov.tr/eskiler/2021/03/20210310-2.htm 
çağırdılar. Hazırda bekleyen insanlarmışız gibi davranıyorlar. Bir arkadaşımız il dışına, ailesinin yanına gitmiş ücretsiz izindeyken. 'Bilgisayarını da götürseydin, akşam bilet al gel' dediler. 24 saat çalışan olarak görüyorlar. 'Evde sizden başka kimse interneti kullanmayacak' diye sözleşme yaptırdılar. Çünkü parasını şirket ödüyor. Bu yüzden çocuğu online eğitim gören arkadaşlarımız evlerine ek internet almak zorunda kaldı. İş çıkışınızı veririz diye tehdit ettiler bu durum için.” (Murat, Odak Grup Görüşmesi, 2021)

Evden çalışmanın bu olumsuz durumlarına karşın kimi çalışanlar hem sağlık açısından hem de evlerindeki konfor sebebiyle evden çalışmayı olumlu karşılayabilmektedir:

"Çok memnunum. Şirkette çok ses var, boğazımı çok etkiliyordu. Sürekli beni rencide edip baskı kuran da yok evde." (Zuhal, Derinlemesine Görüşme, 2021)

Çalışanların pandemi sürecindeki evden çalışmayı olumlu yönde görmelerinin bir diğer sebebi de çalışanların işe gitmek için uzun yollara katlanmak zorunda kalmaması ve diledikleri kıyafetle ve diledikleri biçimde çalışma "özgürlügüne” sahip olmaları olarak görülmektedir:

“Mesaim 09.00'da başlıyor, 9'a 10 kala uyanıp pijamalarımla bilgisayarın başına geçebiliyorum.” (Tülay, Derinlemesine Görüşme, 2021)

"Ağustostan beri evden çalışıyoruz. Yol ve iş için hazırlanmak gibi vakit kayıplarımız olmuyor, bu açıdan olumlu.” (Selma, Derinlemesine Görüşme, 2021)

Ancak çalışanların evden çalışmanın olumlu olarak niteledikleri özelliklerinin yanında araştırma sorularına verdikleri yanıtlar göz önünde bulundurulduğunda olumsuz özelliklerinin daha fazla olduğu sonucuna varılmaktadır. Çalışanlar pandemi dönemindeki çalışma düzeninde kulaklıklarıyla neredeyse modern prangalara bağlı olduklarını, pandemi süresince şirket tarafından destek görmediklerini aksine denetleme mekanizmalarının daha katı biçimde işletildiğini aktarmışlardır:

"Pandemiden önce bu kadar mesaimiz yoktu. 2 gün iznimiz de 1 güne indirildi." (Güzide, Derinlemesine Görüşme, 2021)

"Ne kıyamet olursa olsun çağrı merkezi çalışanları çalıştı, çalışacak. Dünya y1kılsa bize izin vermezler, ben bunu anladım." (Gamze, Derinlemesine Görüşme, 2021)

"Covid'de çok geç kalındı. Kimsenin vicdanı sızlamıyor. Yeter ki banka kazansın. Ayrıca pandemi döneminde çağrı gelince bilgisayarlarımızın kameraları otomatik açllyyor. Ev hapsi gibi. Pandemi olmasa bir nebze iyi, çıkıp dolaşırsın. Ama şu an zaten ülkenin durumu çok kötü. 2 gün iznin 1 güne düşüyor ki o da hafta sonu, zaten yasak var.” (Zafer, Odak Grup Görüşmesi, 2021)

"Hazır kıta nöbetçisi, asker gibiyiz. Ben dahil birçok kişi psikiyatriye gidiyoruz, ilaç kullanyyoruz.” (Behçet, Odak Grup Görüşmesi, 2021)

Araştırma kapsamında katılımcıların pandemi sürecinin iş yüklerini azaltıp azaltmadığ1 sorularına verdikleri yanıtlar, çalışma koşullarının olumsuzluklarının pandemi döneminde keskinleştiğini ve şirketlerin kârlarının artmasına rağmen bu durumun 
çalışanlara olumlu biçimde yansıtılmadığını göstermektedir. Çalışanların çoğunun "nasılsa evdesiniz" mantığıyla mesai ücretleri, yemek ücretleri ödenmemekte ve çalışanlar çağrılarının kayıt altına alınmasının yanı sıra bilgisayarlarının kameraları aracılığıyla da gözetim pratiklerine tabi tutulmaktadır:

“9-7 eve kilitlisin. Dışarıda ölümler oluyor, arkadaşlarını göremiyorsun. Evdeyim ama o gözü hissediyorum. Evdesin ama özgür değilsin. 'Pandemide herkes işten çıkarıldı. Siz çok şanslısınız, bizim şirketimiz kimseyi yüz üstü bırakmadı' diyorlar. Sanki babamın hayrına çalışıorum. Sürekli bir panoptikon.” (Tülay, Derinlemesine Görüşme, 2021)

$\mathrm{Bu}$ nedenle çağrı merkezi çalışanlarının pandeminin sağlık ve sosyal ilişkiler açısından her bireyi etkilediği düzeydeki endişe, kaygı, korku gibi olumsuz duyguları, çalışma biçimlerinin bu özellikleri nedeniyle pekişmektedir.

\section{Sonuç}

Duyguların araç olarak kullanımı özellikle hizmet sektöründe giderek artmakta, hizmet sektöründe faaliyet gösteren şirketlerin çalışanların fiziksel ve zihinsel emeklerinin yanı sıra duygusal emeklerinden de faydalanarak kârlarını arttırma hedefi gütmektedir. Duygusal emek kavramı, kendi içinde üretken emekten bağımsız ya da hizmet sektörü açısından doğrudan somut bir ürün çıktısının olmaması sebebiyle maddi emekten ayrı düşünülse de çağrı merkezi çalışanlarının deneyimlediği çalışma koşulları açısından oldukça somut bir yer tutmaktadır. Ancak araştırmanın amacı çağrı merkezi çalışanlarının maddi bir emek ürünü ürettiklerini kanıtlamak değil, çağnı merkezi çalışanlarının çalışma koşulları bağlamında duygusal emek süreçlerinin analiz edilmesi olarak açıklanmaktadır. Bu nedenle çağnı merkezi çalışanlarının gerçekleştirdiği emek üretiminin maddi olup olmadığı konusunda birçok etmen öne sürülebilecek olsa da araştırma kapsamında çağrı merkezi çalışanlarının hem içinde bulundukları sömürü ilişkileri hem de günümüzün hizmet sektörünün çalışma koşullarında giderek keskinleşen olumsuz durumlar, çağnı merkezi çalışanlarının sınıfsal konumlarının açıklanması kilit rol oynamaktadır.

Araştırma kapsamında çağrı merkezlerinin çalışma koşulları açısından birçok hak gaspını içinde barındırdığı görülmüştür. Çalışanlar mola haklarının gasp edilmesi, mesai saati kavramının silikleşmesi, kota doldurma veya satış baskısı gibi birçok olumsuz durumla yüz yüze gelmektedir. Mola haklarının gasp edilmesi çalışanların dinlenmelerini engellemekte, çalışma süreleri boyunca dinlenemedikleri için verimli bir çalışmada bulunamamakta, sürekli strese ve gerginliğe dayalı bir çalışma hayatı yaşamalarına sebep olmaktadır. Aynı zamanda kota doldurma ve satış baskısı da çalışanların çalışma hayatındaki huzursuz ve gergin hislerinin bir diğer sebebi olarak ortaya çıkmaktadır. Bu baskı ile rekabet unsurları çalışanların çalışma hayatlarında güvensiz hissetmesine sebep olmakta, mesleki sadakat duygusu geliştirememelerine sebep olmaktadır. Esnek ve kuralsız bir biçimde istihdam edilen çalsşanlar her an işlerini kaybetme korkusu yaşamakta, işin içeriğinin sürekli değişebileceğinin farkında olmakta ancak bunların ne zaman olacağını bilememektedir. Bu durum çalışanları hem çalışma yaşamlarında hem de özel hayatlarında güvensiz ve güvencesiz bir yaşama sıkıştırmaktadır. Bu sıkışma hali, çalışanların kendi değerleri hakkında olumsuz düşünmelerine de yol açmaktadır.

Çalışanların kendileri hakkında olumsuz düşüncelere kapılmasının en temel sebebi, yaptıkları işin hem mevcut çalışma koşulları hem de işin toplumsal düzlemdeki karşıllı̆ 
sebebiyle değersiz kılınması olarak görünmektedir. Araştırmaya katılan katılımcıların 19'u üniversite mezunu, 1’i doktora öğrencisi, 1'i üniversite öğrencisi, 2'si lise mezunu ve 1'i önlisans mezunudur. Bu durumda çağrı merkezlerinde çalışanların çoğunluğunu eğitim almış gençlerin oluşturduğu söylenebilmektedir. Üniversiteyi bitirmiş gençler, kendilerini mesleki aidiyetleriyle var etmek istemektedir. Ancak mesleklerinin toplumsal sayginlık elde etmelerini sağlayamaması ve gerek çalışma hayatlarında gerek özel hayatlarında kendilerini "işe yarar hissedememeleri”" kendilerini sürekli olarak değersiz hissetmelerine sebep olmaktadır. Bu durum çalışanların duygusal açıdan oldukça yoğun bir biçimde yıpranmalarına sebep olabilmektedir.

Aynı zamanda çağnı merkezi çalışanı ya da müşteri temsilcisi sıfatıyla toplumda değer görmeyeceklerini düşünen çalışanlar, "yeni işlerin icadı" tartışması ekseninde yeni işler icat etmeseler de mesleklerini yeni ve daha "havalı" olduğunu düşündükleri isimlerle değiştirme çabası gütmektedir. Müşteri temsilcisi yerine iletişim uzmanı sıfatını kullanmaları bu durumu örneklemektedir. Bu durum, günümüzün kuralsız istihdam rejiminin somut durumunu ortaya koymaktadır. Geçmişte birey hayatı boyunca tek bir işte çalışmakta, toplum açısından işe yarar hissetmektedir. Günümüzde bu durum söz konusu olmamakta, bireyler yaşamları boyunca birden fazla işte oldukça kısa sürelerde çalışabilmektedir. Ancak bu noktada bu durumun çalışanlara özgürlük vaat ettiği, bu nedenle çalışanları özerkleştirdiği yanılgısına düşmemek gerekmektedir. Aksine bu durum bir güvencesizlik tuzağ ${ }^{7}$ yaratmaktadır.

Çalışanların deneyimlediği bu güvencesiz ve stres dolu çalışma yaşamı koşulları, pandemi süreciyle şiddetini arttırmaktadır. Pandemi süresince evden çalışma sistemine geçilen çağrı merkezi sektöründe çalışanların maruz bırakıldığı esnek çalışma biçimlerinin olumsuz etkisi giderek artmaktadır. Çalışanların tüm gün evde olmaları sağlık açısından güvende olmaları gibi olumlu yanlarının yanı sıra, "nasılsa evdesiniz" denilerek tüm yaşamlarının işe bağlı kılınmasını beraberinde getirmiştir. Pandemi sürecinden önce gerek bedensel gerek zihinsel yorgunluklarından gerekse tüm gün telefondan konuşmaktan kaynaklı olarak sosyalleşmek istemeyen, isteseler de sosyalleşemeyen çalışanlar, pandemi sürecinde evden çalışma sistemine geçilmesiyle ev içindeki aileleriyle dahi iletişim kurmakta tahammülsüzleşmektedir. Araştırma sonucunda pandemi sürecinin çağrı merkezi çalışanlarının iş yükünü arttırdığı görülmüştür. İşs yüklerinin artmasının yanı sıra çalışanlardan tüm gün evde oldukları için takım liderleri tarafından mesai saatleri dışında işler istenebilmekte, çağrı hatlarının çok yoğun olduğu zamanlar çă̆rı almaları beklenebilmektedir. Aynı zamanda pandemi ve evden çalışma, çağrı merkezi çalışanlarının iş mekanındakinden farklı bir gözetime tabi tutulmasına yol açmaktadır. Özellikle kimi işyerleri çağnı esnasında çalışanların bilgisayarlarının kameralarını açan bir sistem ile çalışarak çalışanların özel alanlarına müdahale etmekte, çalışanlar üzerinde devamlı ve sistematik bir

7 Güvencesizlik tuzağı, Guy Standing'in prekaryayı tarif ederken kullandığı anlamıyla günümüzün esnek çalışma biçimlerinin karakterinin anlaşılması amacıyla kullanılmıştır. “... İssiz kalınan durumlarda yeni başvurulara harcanan zaman, bu dönemde elde edilen gelirin kesintiye uğraması, iş aramakla ilgili zaman ve çeşitli giderler, yeni işteki rutinleri öğrenme maliyeti, yeni geçici işlerin gerektirdiği unsurlara alışmak için iş dışındaki aktivitelere adapte olma maliyeti gibi şeyler karşımıza çıkar. Beklenen kazançlarla karşılaştırıldığında ortaya çıkan toplam önemli bir miktara ulaşmış olabilir. Bu da güvencesizlik tuzağı denilen duruma neden olur (Standing, 2020, s. 88)" 
baskı unsuru oluşturmaktadır. Çağrılarının sürekli kayıt altına alındığının ve sürekli izlendiklerinin bilincindeki çalışanlar, hep kendilerini kontrol etmek zorunda kalmaktadır. $\mathrm{Bu}$ durum aynı zamanda çalışanların çalışma esnasında sarf ettikleri duygusal emek süreçlerini de olumsuz yönde etkilemektedir. Çünkü çalışanlar duygusal açıdan müşterilerle belli konularda empati kurmakta, yardım etmek istemektedir. Fakat şirket tarafindan çalışanların bu duygularını belli etmemeleri, yalnızca satış gerçekleştirmeleri ve bunu gerçekleştirirken de şirketin belirlediği standart iletişim biçimlerini kullanmaları istenmektedir. $\mathrm{Bu}$ durum çalışanların çalışma hayatlarında duygusal uyumsuzluk yaşamalarına sebep olmaktadır.

Çağrı merkezlerinin istihdam açısından genç ve kadın yoğun bir sektör olması da çă̆rı merkezi çalışanlarının duygusal emek süreçlerini farklı biçimlerde etkilemektedir. Araştırma kapsamında gençlerin üniversiteden mezun olduklarında iş bulamadıkları için çağnı merkezinde çalışmaya başladıkları görülmüştür. Ancak gerek çalışma koşulları gerekse rekabete dayanan çalışma biçimi sebebiyle gençler, çağnı merkezinde çalışmayı bir kariyer hedefi olarak görememektedir. Bu nedenle çağrı merkezinde çalışmanın gençler için ya bir basamak rolü oynadığı ya da ücret ve sosyal haklar anlamında daha olumlu şartlara sahip olan bir iş bulana kadar geçici bir iş rolü üstlendiği görülmüştür. Kadınlar açısından ise çağrı merkezlerinin özellikle mobbing ve sözlü taciz şeklinde bir olumsuz yanı bulunmaktadır. Katılımcıların araştırma sorularına verdikleri yanıtlar bağlamında çağnı merkezlerinde kadın çalışanların erkek çalışanlara nazaran daha yoğun bir biçimde sözlü tacize maruz kaldıkları anlaşılmaktadır. Müşteriler, kadın çalışanlara sözlü tacizde bulunabilmekte, işverenler ya da takım liderleri de kadın çalışanları yedek iş gücü ordusu açısından ikame edilebilir gördükleri için daha kolay gözden çıkarabilmektedir. Bu durumun kadın çalışanların daha fazla ve sık biçimde mobbinge maruz kalmasına yol açtı̆̆ı söylenebilmektedir. Kadınlara yüklenen toplumsal cinsiyet rolleri de düşünüldüğünde çağrı merkezinde çalışmanın kadınlar açısından taciz ve mobbingin yanı sıra farklı olumsuzluklar barındırdığı da vurgulanmalıdır. Özellikle pandemi sürecinde çağrı merkezlerinde evden çalışmaya geçilmesi, kadınların ev içi bakım yüklerini arttırmıştır. Bu durumun temel sebebi ise ev içi bakımın kadınların sorumluluğu olarak görülmesidir.

Sonuç olarak araştırmanın bulguları göz önünde bulundurulduğunda çağrı merkezlerindeki çalışma koşullarının çalışanların duygusal emek süreçleri üzerinde olumsuz etkide bulunduğunu söylemek mümkündür. Özellikle çalışanların giderek daha fazla esnek çalışma biçimlerine ve bunun sonucunda daha katı denetim mekanizmalarına maruz bırakılması çalışanların duygusal emek süreçlerinden kaynaklanan olumsuz deneyimlerini pekiştirmektedir. Bu durum çalışanlara duygusal açıdan tükenme, değersizlik, stres ve kayg1 gibi olumsuz duygular biçiminde yansımaktadır. Çă̆rı merkezlerinde pandemi sürecinde evden (uzaktan) çalışmaya geçilmesi de çalışanların bu duyguları hissetmesini arttırıyor görünmektedir. Evden (uzaktan) çalışma sistemiyle çalışanların çalışma hayatı - özel hayat ayrımlarının giderek ortadan kaldırılması, her an kendilerini çalışırken bulabilmeleri, karmaşıklaşan ve hayatlarının her alanına sirayet eden denetlenme mekanizmaları çalışanlar açısından duygusal emek süreçlerinin olumsuzluklarını keskinleştirmektedir. 


\section{KAYNAKÇA}

Akalın, A. (2007). Duygulanım ve Duygulanımsal Emek Üzerine Notlar. Birikim(217), 114-121.

Akpınar, T. (2016). Sendikal Harekette Alternatif Arayışlara Dayanak Oluşturacak Sosyolojik Gerçekliğin Bilgisine Sahip Miyiz? Emek Araștırma Dergisi (GEAD), 7(10), 51-68.

Başç1, E. (2018). AVM'lerdeki Satış Görevlilerinin Çalısma Koşullar ve Deneyimleri: İzmir'de Sosyolojizk Bir Saha Araștrması. Eskişehir: Anadolu Üniversitesi Sosyal Bilimler Enstitüsü Sosyoloji Ana Bilim Dalı Doktora Tezi.

Biçkes, D. M., Yılmaz, C., Demirtaş, Ö. ve Uğur, A. (2014). Duygusal Emek ile İş Tatmini Arasındaki İlişskide Psikolojik Sermayenin Aracılık Rolü: Bir Alan Çalışması. Eskişebir Osmangari Üniversitesi IIIBF Dergisi, 9(2), 97-121.

Bilir Kat, Z. E. (2016). Eğretilesme ve Duygusal Emek Sürecleri: Alssveriş Merkęlerinde Calışan Kadinlar Örneği. Ankara: Ankara Üniversitesi Kadın Çalışmaları Ana Bilim Dalı Yüksek Lisans Tezi.

Cengiz, A. (1998, 08 01). "Kapitalizm Ötesi" Tezler ve Isşçi Simffi. 03 18, 2020 tarihinde Özgürlük Dünyası: https://ozgurlukdunyasi.org/arsiv/342-sayi-091/1285qkapitalizm-otesiq-tezler-ve-isci-sinifi adresinden alındı

Çukur, C. (2016). Türk Hukuku ve Karşılastrtrmah Hukukta Iss Yerinde Psikolojik Taciz: Ankara: TBMM Araştırma Merkezi Yayınları.

Hardt, M. ve Negri, A. (2003). Imparatorluk. (A. Yılmaz, Çev.) Ayrnntı Yayınları: İstanbul.

Harvey, D. (2014). Postmodernliğin Durumu. (S. Savran, Çev.) İstanbul: Metis.

Hochschild, Arlie R. (1983). The Managed Heart: The Commercialization of Human Feeling. Berkeley and Los Angeles: University of California Press.

İlhan, S. (2008). Yeni Kapitalizm ve Meslek Olgusunun Değişen Anlamları Üzerine. Dumlupinar Üniversitesi Sosyal Bilimler Dergisi(21), 313-328.

Karaman, N. (2017). Çalışma Yaşamında Duygusal Emek. İş ve Hayat, 3(5), 30-56.

Kaya, U. ve Serçeoğlu, N. (2013). Duygu İşçilerinde İşe Yabancılaşma: Hizmet Sektöründe Bir Araştırma. Callşma ve Toplum, 311-346.

Kızıltaş, K. (2019). Yeni Kapitalizm: Üretim Süreci ve Prekaryalasma. Edirne: Trakya Üniversitesi Çalışma Ekonomisi ve Endüstri İlişkileri (Yüksek Lisans Tezi).

Koşar, A. (2017). Negri, Simuf ve Çokluk - Postmodern Özne Arayışmın Eleştirisi. İstanbul: Kor Kitap.

Man, F. ve Selek Öz, C. (2009). Göründüğü Gibi Olamamak ya da Olduğu Gibi Görünememek: Çağr1 Merkezlerinde Duygusal Emek. Çalışma ve Toplum(1), 75-94.

Oğuz, Ş. (2011). Tekel Direnişinin Işığında Güvencesiz Çalışma/Yaşama: Proletaryadan "Prekarya"ya mı? Mülkijye, 35(271), 7-24.

Savul, G. (2015). Gayri-Maddi Emeğin Üretkenleşmesi: Talihsizliğin Görünümleri. Calsma ve Toplum, 293-322. 
Sennett, R. (2017). Yeni Kapitalizmin Kültürü. İstanbul: Ayrıntı Yayınları.

Sennett, R. ve Cobb, J. (2018). Simıın Giẓli Yaraları. Ankara: Heretik Yayıncilik.

Standing, G. (2020). Prekarya: Yeni Teblikeli Sımı. İstanbul: İletişim Yayınları.

Tekin,G. (22.05.2020). Metal işçileri: MESS-Safe uygulaması kölelik düzenini hatırlatıyor. Kocaeli: Evrensel Gazetesi. URL: https://www.evrensel.net/haber/405289/metaliscileri-mess-safe-uygulamasi-kolelik-duzenini-hatirlatiyor/ (Erişim Tarihi: 25.05.2020)

Uca, O. (2015). Kitlesel İşciden Toplumsal Issciye: Maddi Olmayan Emek ve Beyaz Yakahlar. Yayınlanmamış Doktora Tezi, Ege Üniversitesi Sosyal Bilimler Enstitüsü, Kurumlar Sosyolojisi Ana Bilim Dal, İzmir.

Yücesan - Özdemir, G. (2014). Inatç Köstebek - Căğr Merkęlerinde Gençlik, Sinıf ve Direniş. İstanbul: Yordam Kitap. 